\title{
AGRONOMIC PERFORMANCE AND ADAPTABILITY OF ARABIC COFFEE RESISTANT TO LEAF RUST IN THE CENTRAL BRASILIAN SAVANNA
}

\author{
Adriano Delly Veiga ${ }^{1}$, Omar Cruz Rocha ${ }^{2}$, Antônio Fernando Guerra ${ }^{3}$, Gabriel Ferreira Bartholo ${ }^{4}$, \\ Gustavo Costa Rodrigues ${ }^{5}$, Welington Pereira ${ }^{6}$, Thiago Paulo da Silva ${ }^{7}$, Evandro Ribeiro da Silva ${ }^{8}$
}

(Received: November 24, 2016; accepted: Monday, May 8, 2017)

\begin{abstract}
Breeding programs and later indication of rust resistant cultivars for different environments and crops systems, in the concept of diseases integrated control, reach out for productivity raising and reduced production costs. The aim of this work was to evaluate the agronomic performance and adaptability of new Coffea arabica cultivars and progenies resistant to leaf rust in Central Brazilian Savanna. The experiment has been conducted since 2008 in an experimental area of Embrapa Hortaliças. Twenty three resistant cultivars, four progenies and three susceptible cultivars as controls, were assessed in a complete randomized block design with four replicates. The following traits were analyzed: plant height, stem diameter, canopy projection, number of plagiotropic branches, yield, grains percentage retained in sieves above 17, grain ripening and diseases resistance. Catucaí 2SL, Sacramento and Araponga stood out in vegetative growth. The highest yields are observed for IPR 103, Obatã 1669-20, Palma II, Sabiá 398 and Acauã, with values higher than 60 sacks per hectare. Among all these cultivars is observed high resistance to rust leaf and greater susceptibility to brown eye spot in the cultivar Acauã, for the place and period of evaluation.
\end{abstract}

Index terms: Coffea arabica, adaptability, diseases, productivity, vegetative growth.

\section{DESEMPENHO AGRÔNOMICO E ADAPTABILIDADE DE CAFEEIRO ARÁBICA RESISTENTE À FERRUGEM NO CERRADO DO PLANALTO CENTRAL}

RESUMO: O trabalho do melhoramento e posterior indicação de cultivares resistentes à ferrugem para diferentes ambientes e sistemas de cultivo, dentro do controle integrado de doenças, visa aumento de produtividades e redução de custos de produção. Com objetivo de avaliar desempenho agronômico e adaptabilidade de novas cultivares e progênies de café arábica com resistência à ferrugem, nas condições de Cerrado do Planalto Central do Brasil, foi instalado em 2008 um ensaio na área experimental da Embrapa Hortaliças. Os tratamentos foram 23 cultivares e quatro progênies resistentes à ferrugem além de três cultivares suscetíveis, utilizadas como controle. O experimento foi conduzido com o delineamento em blocos ao acaso com quatro repetições e parcelas de 10 plantas. As características avaliadas: altura de plantas, diâmetro de caule, projeção da copa, número de pares de ramos plagiotrópicos, produtividade, porcentagem de grãos retidos nas peneiras acima de 17, maturação dos grãos e incidência e severidade das doenças. As cultivares Catucaí 2SL, Sacramento MG e Araponga MG destacaramse em crescimento vegetativo. As cultivares com maiores produtividades médias, acima de 60 sc.ha-1, apresentando maior adaptabilidade às condições ambientais são IPR 103, Obatã Vermelho 1669-20, Palma II, Sabiá 398 e Acauã. Para todas estas cultivares observa-se alta resistência a ferrugem e maior suscetibilidade a cercosporiose na cultivar Acauã, para o local e período de avaliação.

Termos para indexação: Coffea arabica, adaptabilidade, doenças, produtividade, crescimento vegetativo.

\section{INTRODUCTION}

Brazil is the world's largest producer and exporter of coffee, with a production of about 49 million bags processed in $2016,81 \%$ of which represented by arabica coffee (Coffea arabica). The area cultivated with C. arabica was about 1.76 million hectares, of which $86 \%$ is in production and the remaining in stage of growth (COMPANHIA NACIONAL DE ABASTECIMENTO - CONAB, 2016). The crop has potential for expansion in regions such as the savanna of the central plateau, due to favorable weather conditions, topography that allows using machines in the production system, with the possibility of achieving high productivity and quality, besides reducing production costs (FERNANDES et al; 2012).

Coffee leaf rust was found in the country in 1970 and soon spread out to lots of coffee regions. Its damages are mainly indirect ones, resulting in defoliation, smaller setting of flowers, lower setting of pinhead fruits, and drying of plagiotropic branches, compromising in some cases over $50 \%$ of the production (GARÇON et al., 2004).

1,2,7,8 Embrapa Cerrados - Rod. BR 020 Km 18 - Planaltina - DF - 73.310-970 - adriano.veiga@embrapa.br, omar.rocha@embrapa.br, thiagopaulodasilva@hotmail.com, evandrotota190@gmail.com

${ }^{3,4}$ Embrapa Café - Parque Estação Biológica, Av. W3 norte - Brasília - DF - 70.770-901 - antonio.guerra@embrapa.br, gabriel.bartholo@embrapa.br

${ }^{5}$ Embrapa Informática Agropecuária - Av. André Tosello n. 209-Campus Unicamp-Campinas - SP-13.083-886 - gustavo.rodrigues@embrapa.br

${ }^{6}$ Instituto Federal Goiano - Rod. GO 154 km 3 - Campus Ceres - GO - 76300-000 - wellpe2@gmail.com

Coffee Science, Lavras, v. 13, n. 1, p. 41 - 52, jan./mar. 2018 
The disease incidence and severity as well as its damages vary according to the genotype, region, crop year and grain loading causing significant losses (PAIVA et al., 2011).

The resistance factors of coffee trees are $\mathrm{SH} 1$ to $\mathrm{SH}$, in contrast to the respective virulence factors $\mathrm{v} 1$ to $\mathrm{v} 9$, present individually or in combinations, in 45 identified races around the world. Most of the $C$. arabica $L$. cultivars derived from the varieties Típica, introduced in Brazil in 1727, and Bourbon are both susceptible to coffee leaf rust (ANTHONY et al., 2001). In the country, cultivars still widely planted as germplasms of Mundo Novo and Catuaí are carriers of the SH5 gene. Thus, the race II with the v5 gene has a greater geographical distribution and is found in all producing states (DEL GROSSI, 2011).

The research and technology transfer from institutions linked to the supply chain have made a number of technologies available that increase productivity and income to the producer. Within the scope of breeding, new cultivars resistant to coffee leaf rust have been released for commercial use, and information on behavior and performance in distinct regions is important for selecting genotypes most adapted to edaphoclimatic conditions and cropping systems (CARVALHO, 2011).

The genotype is considered as adapted when as adapted when it positively assimilates the stimulus from environmental conditions (MARIOTTI et al., 1976), and this adaptation to a specific environment can determine differences among cultivars to be recommended.

Within a concept of integrated diseases control and the use of different methods and alternatives to reduce disease occurrence and losses to the producers, the indication of high yield cultivars with excellent agronomic characteristics and rust resistance for different environments and crop systems aims at reducing production costs and risks to rural workers and the environment, besides increase the income of the coffee grower.

Thus, the aim of the present study was to assess the agronomic performance and adaptability of new $C$. arabica cultivars and progenies resistant to coffee leaf rust, under the savanna conditions of central plateau of Brazil.

\section{MATERIAL AND METHODS}

The experiment was carried out in the savanna region of the central plateau in 2008, at the Embrapa Hortaliças experimental area, in the DF-158 highway, Gama, DF, Brazil. The area is characterized by the following coordinates and edaphoclimatic conditions: $15^{\circ} 56^{\prime} 00^{\prime \prime} \mathrm{S}$, $48^{\circ} 08^{\prime} 00^{\prime \prime} \mathrm{W}$, with an altitude of $997.2 \mathrm{~m}$. It is a flat area of dark red latosol with clayey texture and presents an annual average rainfall of $1400 \mathrm{~mm}$, with two typical rainy and dry seasons and annual average temperature of $22^{\circ} \mathrm{C}$.

The treatments composed by the specific cultivars and progenies and the institutions that developed them are listed in Table 1, with 23 cultivars and four progenies resistant to coffee leaf rust, besides three cultivars susceptible to coffee leaf rust, used as control (Topázio MG 1190, Catuai Vermelho IAC 144, Catuai Amarelo IAC 62).

The experiment was performed with a spacing of $3.50 \times 0.7 \mathrm{~m}$ in order to replicate the typical spacing of mechanized coffee growing performed in the savanna region. The irrigation system used was sprinkling and the sprinklers were modified as the plants grew. The cultural practices followed the common technical recommendations for coffee growing (fertilization, phytosanitary management, thinning, and mechanical and/ or manual control of weeds). The irrigation was suspended in the period between June 24 and September 4 (deadline), aiming at reaching uniformity of flowering and higher yield of coffee in the cherry stage (GUERRA; ROCHA; RODRIGUES, 2005). The annual phosphorus supply was $300 \mathrm{~kg} \mathrm{P}_{2} \mathrm{O}_{5} /$ ha, divided in two thirds after irrigation was restarted in September - after flowering standardization - and one third in December. For the supply of nitrogen and potassium in each crop season, $450 \mathrm{~kg} / \mathrm{ha}$ of the nutrient were used, divided in four times, the first one after irrigation was retaken and the others starting in December. For micronutrients, $100 \mathrm{~kg}$ FTE/ha were used, spread on the soil in December.

The characteristics which were assessed annually were: 1) Plant height: measured in meters, after harvest, from the base to the apical bud of the stem; 2) Stem diameter: measured in millimeters at the plant base, using a caliper; 3) Canopy projection: measured in meters, approximately 1 $\mathrm{m}$ from the ground crosswise to the planting line; 4) Number of pairs of plagiotropic branches: sum of all productive branches on the plant faces; 5) Productivity: measured in kilograms of cherry coffee of six plants, with fruits dried up to $12 \%$ moisture content and converted into $60 \mathrm{~kg}$ bags of processed coffee per hectare (bg/ha). 
TABLE 1 - List of Coffea arabica cultivars and progenies resistant to coffee leaf rust and controls used in the assay.

\begin{tabular}{|c|c|c|}
\hline Treatment & Cultivar/Progeny & Institution \\
\hline 1 & Catucai Amarelo 2SL & PROCAFÉ \\
\hline 2 & Catucaí Amarelo 24/137 & PROCAFÉ \\
\hline 3 & Catucaí Amarelo 20/15 cv 479 & PROCAFÉ \\
\hline 4 & Catucaí Vermelho 785/15 & PROCAFÉ \\
\hline 5 & Catucaí Vermelho 20/15 cv 476 & PROCAFÉ \\
\hline 6 & Sabiá 398 & PROCAFÉ \\
\hline 7 & Palma II & PROCAFÉ \\
\hline 8 & Acauã & PROCAFÉ \\
\hline 9 & Oeiras MG 6851 & EPAMIG \\
\hline 10 & Catiguá MG 1 & EPAMIG \\
\hline 11 & Sacramento MG & EPAMIG \\
\hline 12 & Catiguá MG 2 & EPAMIG \\
\hline 13 & Araponga MG & EPAMIG \\
\hline 14 & Paraíso MG & EPAMIG \\
\hline 15 & Pau Brasil MG & EPAMIG \\
\hline 16 & Tupi IAC 1669-33 & IAC \\
\hline 17 & Obatã Vermelho IAC 1669-20 & IAC \\
\hline 18 & IPR 59 & IAPAR \\
\hline 19 & IPR 98 & IAPAR \\
\hline 20 & IPR 99 & IAPAR \\
\hline 21 & IPR 103 & IAPAR \\
\hline 22 & IPR 104 & IAPAR \\
\hline 23 & Catiguá MG 3 & EPAMIG \\
\hline 24 & Topázio MG 1190 & EPAMIG \\
\hline 25 & Catuaí Vermelho IAC 144 & IAC \\
\hline 26 & H419-3-3-7-16-4-1 & EPAMIG \\
\hline 27 & H419-10-6-2-5-1 & EPAMIG \\
\hline 28 & H419-10-6-2-10-1 & EPAMIG \\
\hline 29 & H419-10-6-2-12-1 & EPAMIG \\
\hline 30 & Catuaí Amarelo IAC 62 & IAC \\
\hline
\end{tabular}

6) classification of beans in sieves: a sample of 300 $\mathrm{g}$ went through the set of sieves and the percentage above the sieve 17 was checked; 7) Uniformity of maturation: percentage of cherry and unripe fruits at the harvesting time of plots; 8) Assessment of incidence and severity of coffee leaf rust and brown eyespot were performed every month, from November 2014 to October 2015, collecting four leaf pairs per plant, totalizing 32 leaves per plot.
The incidence was determined in percentages, counting the number of infected leaves, and the severity was assessed by the diagrammatic scale for coffee leaf rust (MARTINS et al., 2015) and brown eye spot (SOUZA; MAFFIA; MIZUBUTI, 2012). The disease incidence and severity values were turned into an area under the disease progress curve (AUDPC), according to the formula: $\operatorname{AUDPC}=\sum\left[\left(\left(\mathrm{y}_{1}+\mathrm{y}_{2}\right) / 2\right) *\left(\mathrm{t}_{2}-\mathrm{t}_{1}\right)\right]$, where $\mathrm{y}_{1}$ and $\mathrm{y}_{2}$ 
are two consecutive assessments performed at times $\mathrm{t}_{1}$ and $\mathrm{t}_{2}$.

The randomized block design was used with four replicates, each plot consisted of a set of 10 plants. For grain yield, a split-plot in time was considered with the genotypes as a plot and the biennium (2010 and 2011, 2012 and 2013, 2014 and 2015) in the subplot. For vegetative growth, a joint data analysis was performed among the years 2010 and 2014. For the AUDPC data, a variance analysis was performed in the 12 months of disease assessment, from November 2014 to October 2015. The research data were assessed through the Sisvar statistical software (FERREIRA, 2011) and the grouping of means of response variables were performed by Scott-Knott test at 5\% probability.

\section{RESULTS AND DISCUSSION}

The result of the analysis of variance for productivity in three biennia showed that all sources of variation were significant at $5 \%$ at the F test (Table 2).

In this assay, two genotype groups were evidenced in relation to the productivity of processed coffee beans, in the six assessed harvests (Table 3 ). The IPR 103 cultivar, with a Catuaí $x$ Icatu genealogy, presented an average of over 65 bags.ha ${ }^{-1}$, demonstrating high adaptability to environmental conditions. In the first group of cultivars with productivities over 60 bags.ha $^{-1}$ are Obatã Vermelho IAC 1669-20, Palma II, Sabiá 398 and Acauã. Among the higher yield, still intothe first group are Catucaí 2SL, Tupi IAC 1669-33, Araponga MG, IPR 98 and the H419-10-6-2-5-1 progeny.

When the average yield in the six harvests is considered, all genotypes showed values well above the current national average of 22.5 bags. All of them over 37 bags, which is the average for Bahia savannas, the highest values for savanna regions in 2015 (CONAB, 2016). In savanna areas such as the one from the present study,yield and quality can be increased due to weather conditions for a goodvegetative and reproductive development of plants. This is possible with high temperatures, higher levels of insolation, low relative humidity at harvest time, beisdes the possibility of using high technological level with inputs, irrigation and mechanization (FERNANDES et al., 2012).

Carvalho et al. (2012) studied these same cultivars in the South and Alto Paranaíba regions of Minas Gerais, Brazil, and concluded that Sabiá 398, Pau Brasil MG 1, Obatã 1669-20, Catucaí Amarelo 24/137 and IPR 103 are the most promising for the assessed region.
In the Brazilian state of Rondônia, with annual average temperature of $26^{\circ} \mathrm{C}$ and high rainfall levels, an experiment with average yield of 24.6 bags.ha $^{-1}$ was observed, and the Catucaí Amarelo 24/137 and Obatã Vermelho 166020 cultivars stood out as the most productive varieties, with yields of 42.7 and 36.34 bags.ha $^{-}$ ${ }^{1}$ respectively.

The IPR 103 cultivar was also among the most productive in the north of the country, averaging 33 bags.ha $^{-1}$ (TEIXEIRA et al., 2013), and in the South, Alto Paranaíba and Vale do Jequitinhonha regions of Minas Gerais, with averages of 43, 46 and 55 bags.ha $^{-1}$, respectively (CARVALHO et al., 2012), showing high adaptability to different environments and cultivation conditions.

In relation to genotypes with lower yield, Catucaí Vermelho 785/15 and Catiguá MG 1 showed average productivities with differences above $50 \%$, when compared to the one with best performance. Carvalho et al. (2012) also found lower adaptability of this Catucaí cultivar in all assessed sites in the state of Minas Gerais.

By studying the genotypes $\mathrm{x}$ biennium interaction, with data from two consecutive combined harvests, it is possible to ensure greater experimental precision by reducing effects of biennial production in the culture. Regarding the biennials, a higher average yield was observed considering all genotypes in the years 2012/13 and the significant interaction between genotypes and biennia shows differentiated behavior and adaptability in the periods (Table 3 ).

Thus, it is possible to highlight genotypes that did not show significant differences considering the biennials, such as Paraíso MG, Catiguás MG1 and MG3 and Topázio MG 1190. Also ones with high average yield in the first two biennium and reduction in the third, such as Tupi IAC 1669-33, IPR 98, IPR 59 and Catuaí Vermelho IAC 144. Finally, genotypes that presented higher values for the second biennium, such as IPR 103, Palma II, Catiguá MG2 and Catuaí Amarelo 62.

It is possible to observe that cultivars such as Sabiá 398, although highly biennial, show a high productivity average when considering all years, as well as when analyzing biennia 2 and 3 (Table 3). This kind of analysis allows for a more detailed indication of cultivars according to management systems and the desired exploration period of cultivation. Besides, it is possible to measure the longevity of the genotype yield, thus a longitudinal study is needed. 
TABLE 2 - Summary of analysis of variance with means squares for productivity of processed coffee beans.

\begin{tabular}{cccc}
\hline Source & $D F$ & $M S$ & $P r>F$ \\
\hline Genotype & 29 & $524.5^{*}$ & 0.00 \\
Block & 3 & $409.04^{*}$ & 0.006 \\
error a & 87 & 92.38 & 0.0008 \\
Biennium & 2 & $8821.38^{*}$ & 0.00 \\
error b & 6 & 301.04 & $227.97^{*}$ \\
Gx B & 58 & 79.97 & \\
error c & 174 & .
\end{tabular}

*Significant at 5\% probability at $\mathrm{F}$ test.

TABLE 3 - Average yield of six years and per biennium, in $60 \mathrm{~kg}$ bags of processed coffee beans per hectare, of the 30 Coffea arabica genotypes under savanna conditions of the central plateau of Brazil.

\begin{tabular}{|c|c|c|c|c|}
\hline Cultivar/Progeny & B1 & $\mathrm{B} 2$ & B3 & Average \\
\hline Catucai Amarelo 2SL & $49.9 \mathrm{bB}$ & $73.2 \mathrm{aA}$ & $55.1 \mathrm{aB}$ & $59.43 \mathrm{a}$ \\
\hline Catucaí Amarelo 24/137 & $48.6 \mathrm{bA}$ & $53.3 \mathrm{bA}$ & $36.3 \mathrm{bB}$ & $46.06 \mathrm{~b}$ \\
\hline Catucaí Amarelo 20/15 cv 479 & $50.7 \mathrm{bA}$ & $60.2 \mathrm{bA}$ & $40.7 \mathrm{bB}$ & $50.53 \mathrm{~b}$ \\
\hline Catucaí Vermelho 785/15 & $42.9 \mathrm{bA}$ & $44.8 \mathrm{bA}$ & $32.1 \mathrm{bB}$ & $39.93 \mathrm{~b}$ \\
\hline Catucaí Vermelho 20/15 cv 476 & $49.3 \mathrm{bB}$ & $58.9 \mathrm{bA}$ & $42.1 \mathrm{bB}$ & $50.10 \mathrm{~b}$ \\
\hline Sabiá 398 & $44.3 \mathrm{bC}$ & $78.8 \mathrm{aA}$ & $62.8 \mathrm{aB}$ & $61.96 \mathrm{a}$ \\
\hline Palma II & $47.8 \mathrm{bB}$ & $89.9 \mathrm{aA}$ & $48.3 \mathrm{aB}$ & $62.00 \mathrm{a}$ \\
\hline Acauã & $58.6 \mathrm{aB}$ & $80.6 \mathrm{aA}$ & $45.2 \mathrm{bC}$ & $61.46 \mathrm{a}$ \\
\hline Oeiras MG 6851 & $55.5 \mathrm{aA}$ & $64.3 \mathrm{bA}$ & $44.1 \mathrm{bB}$ & $54.63 \mathrm{~b}$ \\
\hline Catiguá MG 1 & $36.4 \mathrm{bA}$ & $49.3 \mathrm{bA}$ & $44.8 \mathrm{bA}$ & $43.50 \mathrm{~b}$ \\
\hline Sacramento MG & $42.0 \mathrm{bB}$ & $54.5 \mathrm{bA}$ & $39.4 \mathrm{bB}$ & $45.30 \mathrm{~b}$ \\
\hline Catiguá MG 2 & $39.7 \mathrm{bB}$ & $63.4 \mathrm{bA}$ & $40.1 \mathrm{bB}$ & $47.73 \mathrm{~b}$ \\
\hline Araponga $\mathrm{MG}$ & $58.5 \mathrm{aB}$ & $72.3 \mathrm{aA}$ & $45.9 \mathrm{bB}$ & $58.90 \mathrm{a}$ \\
\hline Paraíso MG & $43.1 \mathrm{bA}$ & $50.2 \mathrm{bA}$ & $51.8 \mathrm{aA}$ & $48.36 \mathrm{~b}$ \\
\hline Pau Brasil MG & $39.7 \mathrm{bB}$ & $59.5 \mathrm{bA}$ & $44.9 \mathrm{bB}$ & $48.03 \mathrm{~b}$ \\
\hline Tupi IAC 1669-33 & $61.6 \mathrm{aA}$ & $68.4 \mathrm{bA}$ & $48.0 \mathrm{bB}$ & $59.33 \mathrm{a}$ \\
\hline Obatã Vermelho IAC 1669-20 & $62.3 \mathrm{aB}$ & $80.8 \mathrm{aA}$ & $47.5 \mathrm{bC}$ & $63.50 \mathrm{a}$ \\
\hline IPR 59 & $53.1 \mathrm{bA}$ & $59.8 \mathrm{bA}$ & $39.0 \mathrm{bB}$ & $50.63 \mathrm{~b}$ \\
\hline IPR 98 & $63.3 \mathrm{aA}$ & $60.9 \mathrm{bA}$ & $44.6 \mathrm{bB}$ & $56.37 \mathrm{a}$ \\
\hline IPR 99 & $48.5 \mathrm{bB}$ & $60.6 \mathrm{bA}$ & $41.2 \mathrm{bB}$ & $50.10 \mathrm{~b}$ \\
\hline IPR 103 & $63.3 \mathrm{aB}$ & $78.8 \mathrm{aA}$ & $53.7 \mathrm{aB}$ & $65.40 \mathrm{a}$ \\
\hline IPR 104 & $48.9 \mathrm{bA}$ & $58.8 \mathrm{bA}$ & $51.8 \mathrm{aA}$ & $53.17 \mathrm{~b}$ \\
\hline Catiguá MG 3 & $46.1 \mathrm{bA}$ & $50.4 \mathrm{bA}$ & $44.8 \mathrm{bA}$ & $47.00 \mathrm{~b}$ \\
\hline Topázio MG 1190 & $46.1 \mathrm{bA}$ & $56.1 \mathrm{bA}$ & $41.8 \mathrm{bA}$ & $48.00 \mathrm{~b}$ \\
\hline Catuaí Vermelho IAC 144 & $52.9 \mathrm{bA}$ & $58.1 \mathrm{bA}$ & $39.2 \mathrm{bB}$ & $50.06 \mathrm{~b}$ \\
\hline H419-3-3-7-16-4-1 & $58.8 \mathrm{aA}$ & $61.1 \mathrm{bA}$ & $40.1 \mathrm{bB}$ & $53.33 \mathrm{~b}$ \\
\hline H419-10-6-2-5-1 & $53.5 \mathrm{bA}$ & $54.8 \mathrm{bA}$ & $65.3 \mathrm{aA}$ & $57.87 \mathrm{a}$ \\
\hline H419-10-6-2-10-1 & $37.9 \mathrm{bB}$ & $52.8 \mathrm{bA}$ & $53.6 \mathrm{aA}$ & $48.11 \mathrm{~b}$ \\
\hline H419-10-6-2-12-1 & $42.4 \mathrm{bB}$ & $59.5 \mathrm{bA}$ & $59.8 \mathrm{bA}$ & $53.90 \mathrm{~b}$ \\
\hline Catuaí Amarelo IAC 62 & $41.1 \mathrm{bB}$ & $59.4 \mathrm{bA}$ & $46.8 \mathrm{bB}$ & $49.20 \mathrm{~b}$ \\
\hline Average & $49.5 \mathrm{~B}$ & $62.4 \mathrm{~A}$ & $46.2 \mathrm{~B}$ & 52.7 \\
\hline
\end{tabular}

*Averages followed by same lowercase letter on the column and capital on the row belong to the same group statistically at Scott-Knott test. B1: 2010/11 biennium; B2: 2012/13 biennium; B3: 2014/15 biennium.

Coffee Science, Lavras, v. 13, n. 1, p. 41 - 52, jan./mar. 2018 
According to an analysis of variance for percentage of beans classified in sieves above 17 and for fruit maturation, all sources of variation were significant at $5 \%$ at the $\mathrm{F}$ test. In the classification of sieves, it was observed that some genotypes showed retention averages of beans higher than $50 \%$, including those that also had high yields, such as Obatã 1669-20 and Tupi 1669-33. (Table 4).

In coffee breeding programs, a genotype with high productive capacity and a higher percentage of beans classified in higher sieves is desirable (FERREIRA et al., 2005).

The separation through the classification by sieves improves the quality of the final product due to the greater uniformity of beans. In a study by Carvalho et al. (2012), a higher quantity of beans classified in high sieves was also observed, as well as high productivity for the Obatã IAC 1669-20 cultivar.

The maturation uniformity of fruits from the cultivars was assessed, highlighting the percentage of fruits in the cherry and green stages at harvest time (Table 4). The values for cherry fruits were high, varying from $55 \%$ to $80 \%$, indicating variability in the closure of the phenological cycle of each genotype, as well as flowering uniformity with the use of controlled water stress, which is crucial to guarantee a higher number of fruits in this stage. Higher percentages were observed for the IPR 98, IPR 59 and Catiguá MG 3 cultivars, with values above $80 \%$. The Palma II, Sabiá 398 , Oeiras and CatucaíAmarelo20/15 cv 479 cultivars presented high percentage of unripe fruits (above $28 \%$ ), evidencing a behavior of late genotypes in relation to the others. A higher amount of harvested unripe fruits can affect the quality of the beverage because it shows different chemical composition from fruits in advanced stages of maturation (ANGÉLICO et al., 2011).

In the analysis of variance for vegetative growth considering five years of cultivation from the year 2010, a significant effect for genotypes and years, was observed in all response variables. A significant interaction was only detected for stem diameter (Table 5).

The different genotypes showed average plant height ranging from 1.99 to $2.25 \mathrm{~m}$ (Table 6). The cultivars that stood out for this characteristic were Catucaí 2SL, Sacramento MG, IPR 103 and Araponga MG. For the diameter of the orthotropic branch, the genotypes showed average values ranging from 49.37 to $64.34 \mathrm{~cm}$, highlighting Sacramento MG, Obatã 1669-20 and Catucaí 2SL (Table 6).

For the number of pairs of plagiotropic branches, the genotypes showed averages ranging from 55.2 to 61.7, with Araponga MG, Sacramento MG and Topázio 1190 standing out. Regarding canopy projection, average values from 90.4 to $102.4 \mathrm{~cm}$ were found. Catucaí 2SL, Sabiá 398, IPR 99, IPR 103, Acauã, Sacramento MG and Obatã stood out with values higher than $100 \mathrm{~cm}$.

When considering vegetative growth, it is possible to highlight some cultivars assessed for these characteristics, such as Catucaí Amarelo 2SL, Sacramento MG and Araponga MG. However, it is necessary to emphasize that high vegetative development does not imply in high yield, since Sacramento MG, in the assessed environmental and technological conditions, was found in the group with the highest values of height, stem diameter, number of pairs of plagiotropic branches and canopy projection, despite showing one of the lowest values for average yield, with 45.3 bags. ha-1. On the other hand, the IPR 103 and Obatã 1669-20 cultivars were included in the group with the highest values of average yield in the six years, and also with high average values of height and canopy projection.

A more detailed study of genetic and phenotypic correlations between yield and vegetative growth characteristics is needed in order to obtain a better understanding on the behavior of genotypes. Freitas et al. (2007) observed a negative correlation between the number of plagiotropic branches and the canopy diameter. Thus, a plant with high productivity, with a large number of branches in the horizontal position and reduced canopy projection could be used in a density system. For the present study, some of these characteristics were observed for Palma II, but further researches are necessary in order to study the performance of this cultivar in other management and farming systems.

The evaluation of diseases under the studied environment conditions showed variability of resistance and susceptibility among the cultivars. The values for the assessment of the disease progress over the studied period (AUDPC) were estimated for the incidence and severity of diseases. According to analysis of variance, the source of variation genotypes was significant at $5 \%$ at the $\mathrm{F}$ test (Table 7). 
TABLE 4 - Averages of the percentage of beans retained in sieves above 17, percentage of beans in the cherry stage and the percentage of unripe beans for the 30 Coffea arabica genotypes in savanna conditions of central plateau.

\begin{tabular}{llll}
\hline Genotype & S $>17$ & Cherry & Green \\
\hline Catucaí 2SL & $49.2 \mathrm{a}$ & $76.8 \mathrm{a}$ & $14.4 \mathrm{c}$ \\
Catucaí 24/137 & $34.0 \mathrm{c}$ & $64.6 \mathrm{c}$ & $14.6 \mathrm{c}$ \\
Catucaí 20/15 cv 479 & $43.8 \mathrm{~b}$ & $64.4 \mathrm{c}$ & $28.0 \mathrm{a}$ \\
Catucaí 785/15 & $46.4 \mathrm{a}$ & $69.9 \mathrm{~b}$ & $10.0 \mathrm{c}$ \\
Catucaí 20/15 cv 476 & $49.2 \mathrm{a}$ & $67.2 \mathrm{c}$ & $23.5 \mathrm{~b}$ \\
Sabiá 398 & $30.0 \mathrm{c}$ & $60.2 \mathrm{~d}$ & $33.5 \mathrm{a}$ \\
Palma II & $35.7 \mathrm{c}$ & $57.3 \mathrm{~d}$ & $34.3 \mathrm{a}$ \\
Acauã & $30.1 \mathrm{c}$ & $72.3 \mathrm{~b}$ & $16.8 \mathrm{c}$ \\
Oeiras MG & $39.6 \mathrm{~b}$ & $54.6 \mathrm{~d}$ & $30.4 \mathrm{a}$ \\
Catiguá MG 1 & $42.2 \mathrm{~b}$ & $60.8 \mathrm{~d}$ & $23.3 \mathrm{~b}$ \\
Sacramento MG & $16.5 \mathrm{c}$ & $79.0 \mathrm{a}$ & $12.5 \mathrm{c}$ \\
Catiguá MG 2 & $25.1 \mathrm{c}$ & $76.3 \mathrm{a}$ & $16.0 \mathrm{c}$ \\
Araponga MG & $39.1 \mathrm{~b}$ & $77.3 \mathrm{a}$ & $13.8 \mathrm{c}$ \\
Paraíso MG 419-1 & $27.1 \mathrm{c}$ & $77.3 \mathrm{a}$ & $14.8 \mathrm{c}$ \\
Pau Brasil MG & $30.1 \mathrm{c}$ & $76.4 \mathrm{a}$ & $13.5 \mathrm{c}$ \\
Tupi 1669-33 & $53.1 \mathrm{a}$ & $77.9 \mathrm{a}$ & $12.6 \mathrm{c}$ \\
Obatã 1669-20 & $51.9 \mathrm{a}$ & $70.0 \mathrm{~b}$ & $20.8 \mathrm{~b}$ \\
IPR 59 & $44.2 \mathrm{~b}$ & $80.4 \mathrm{a}$ & $10.8 \mathrm{c}$ \\
IPR 98 & $31.6 \mathrm{c}$ & $80.5 \mathrm{a}$ & $10.8 \mathrm{c}$ \\
IPR 99 & $46.9 \mathrm{a}$ & $70.3 \mathrm{~b}$ & $20.5 \mathrm{~b}$ \\
IPR 103 & $46.2 \mathrm{a}$ & $70.0 \mathrm{~b}$ & $22.5 \mathrm{~b}$ \\
IPR 104 & $50.9 \mathrm{a}$ & $78.8 \mathrm{a}$ & $11.0 \mathrm{c}$ \\
Catiguá MG3 & $39.9 \mathrm{~b}$ & $80.0 \mathrm{a}$ & $9.40 \mathrm{c}$ \\
Topázio 1190 & $34.8 \mathrm{c}$ & $72.7 \mathrm{~b}$ & $17.8 \mathrm{c}$ \\
Catuaí 144 & $42.7 \mathrm{~b}$ & $71.7 \mathrm{~b}$ & $16.7 \mathrm{c}$ \\
H419-3-3-7-16-4-1 & $46.4 \mathrm{a}$ & $73.3 \mathrm{~b}$ & $13.5 \mathrm{c}$ \\
H419-10-6-2-5-1 & $20.8 \mathrm{c}$ & $71.6 \mathrm{~b}$ & $19.8 \mathrm{~b}$ \\
H419-10-6-2-10-1 & $15.9 \mathrm{c}$ & $66.3 \mathrm{c}$ & $25.6 \mathrm{~b}$ \\
H419-10-6-2-12-1 & $19.8 \mathrm{c}$ & $77.0 \mathrm{a}$ & $13.5 \mathrm{c}$ \\
Catuaí 062 & $44.7 \mathrm{~b}$ & $71.6 \mathrm{a}$ & $21.8 \mathrm{~b}$ \\
\hline
\end{tabular}

*Averages followed by same lowercase letter on the column belong to the same group by Scott-Knott test. 
TABLE 5 - Summary of analysis of variance with mean squares of the variables: plant height, stem diameter (Diam.), number of pairs of plagiotropic branches (NPP) and canopy projection (CP).

\begin{tabular}{cccccl}
\hline Source & DF & Height & Diam. & NPP & CP \\
\hline Year & 4 & $22.86^{*}$ & $12304.3^{*}$ & $7080.5^{*}$ & $1686.1^{*}$ \\
Rep (Year) & 15 & $0.035^{*}$ & $111.9^{*}$ & $28.99^{*}$ & $792.24^{*}$ \\
Genotypes & 29 & $0.105^{*}$ & $187.17^{*}$ & $53.5^{*}$ & $171.9^{*}$ \\
Ax G & 116 & 0.017 & $40.13^{*}$ & 16.27 & 108.05 \\
Error & 435 & 0.017 & 26.5 & 15.22 & 104.24 \\
\hline
\end{tabular}

*Significant at 5\% probability at $\mathrm{F}$ test.

TABLE 6 - Average values of plant height, stem diameter, number of pairs of plagiotropic branches (NPP) and canopy projection (CP) for the 30 Coffea arabica genotypes under savanna conditions of central plateau.

\begin{tabular}{|c|c|c|c|c|}
\hline Genotype & Height (m) & Diameter $(\mathrm{mm})$ & NPP & $\mathrm{CP}(\mathrm{cm})$ \\
\hline Catucaí 2SL & $2.25 \mathrm{a}$ & $61.69 \mathrm{a}$ & $55.2 \mathrm{c}$ & $102.4 \mathrm{a}$ \\
\hline Catucaí 24/137 & $2.12 \mathrm{~b}$ & $54.49 \mathrm{c}$ & $57.7 \mathrm{c}$ & $94.5 \mathrm{~b}$ \\
\hline Catucaí 20/15 cv 479 & $2.01 \mathrm{c}$ & $49.37 \mathrm{~d}$ & $56.7 \mathrm{c}$ & $99.5 \mathrm{a}$ \\
\hline Catucaí 785/15 & $2.13 \mathrm{~b}$ & $57.79 \mathrm{c}$ & $57.3 \mathrm{c}$ & $98.1 \mathrm{a}$ \\
\hline Catucaí 20/15 cv 476 & $2.08 \mathrm{c}$ & $56.38 \mathrm{c}$ & $55.6 \mathrm{c}$ & $97.2 \mathrm{a}$ \\
\hline Sabiá 398 & $2.11 \mathrm{~b}$ & $51.97 \mathrm{~d}$ & $59.5 \mathrm{~b}$ & $102.3 \mathrm{a}$ \\
\hline Palma II & $2.16 \mathrm{~b}$ & $54.62 \mathrm{c}$ & $59.8 \mathrm{~b}$ & $91.9 \mathrm{~b}$ \\
\hline Acauã & $2.09 \mathrm{~b}$ & $57.19 \mathrm{c}$ & $56.8 \mathrm{c}$ & $100.8 \mathrm{a}$ \\
\hline Oeiras MG & $2.13 \mathrm{~b}$ & $55.15 \mathrm{c}$ & $58.3 \mathrm{~b}$ & $94.3 \mathrm{~b}$ \\
\hline Catiguá MG 1 & $2.02 \mathrm{c}$ & $56.89 \mathrm{c}$ & $57.1 \mathrm{c}$ & $95.6 \mathrm{~b}$ \\
\hline Sacramento MG & $2.23 \mathrm{a}$ & $64.34 \mathrm{a}$ & $61.7 \mathrm{a}$ & $100.2 \mathrm{a}$ \\
\hline Catiguá MG 2 & $2.17 \mathrm{~b}$ & $60.16 \mathrm{~b}$ & $58.5 \mathrm{~b}$ & $96.7 \mathrm{~b}$ \\
\hline Araponga $\mathrm{MG}$ & $2.21 \mathrm{a}$ & $59.73 \mathrm{~b}$ & $61.7 \mathrm{a}$ & $97.5 \mathrm{a}$ \\
\hline Paraíso MG 419-1 & $2.00 \mathrm{c}$ & $55.74 \mathrm{c}$ & $58.9 \mathrm{~b}$ & $99.4 \mathrm{a}$ \\
\hline Pau Brasil MG & $1.99 \mathrm{c}$ & $55.49 \mathrm{c}$ & $55.9 \mathrm{c}$ & $93.6 \mathrm{~b}$ \\
\hline Tupi 1669-33 & $2.00 \mathrm{c}$ & $53.82 \mathrm{c}$ & $56.7 \mathrm{c}$ & $97.7 \mathrm{a}$ \\
\hline Obatã 1669-20 & $2.09 \mathrm{~b}$ & $62.18 \mathrm{a}$ & $56.4 \mathrm{c}$ & $100.5 \mathrm{a}$ \\
\hline IPR 59 & $2.11 \mathrm{~b}$ & $57.40 \mathrm{c}$ & $57.7 \mathrm{c}$ & $97.9 \mathrm{a}$ \\
\hline IPR 98 & $2.08 \mathrm{~b}$ & $55.91 \mathrm{c}$ & $57.7 \mathrm{c}$ & $96.3 \mathrm{~b}$ \\
\hline IPR 99 & $2.16 \mathrm{~b}$ & $54.94 \mathrm{c}$ & $58.3 \mathrm{~b}$ & $101.6 \mathrm{a}$ \\
\hline IPR 103 & $2.22 \mathrm{a}$ & $54.37 \mathrm{c}$ & $58.7 \mathrm{~b}$ & $101.1 \mathrm{a}$ \\
\hline IPR 104 & $2.11 \mathrm{~b}$ & $54.68 \mathrm{c}$ & $58.4 \mathrm{~b}$ & $99.6 \mathrm{a}$ \\
\hline Catiguá MG3 & $2.04 \mathrm{c}$ & $56.08 \mathrm{c}$ & $55.9 \mathrm{c}$ & $94.7 \mathrm{~b}$ \\
\hline Topázio 1190 & $2.14 \mathrm{~b}$ & $59.05 \mathrm{~b}$ & $60.4 \mathrm{a}$ & $95.6 \mathrm{~b}$ \\
\hline Catuaí 144 & $2.13 \mathrm{~b}$ & $55.90 \mathrm{c}$ & $59.0 \mathrm{~b}$ & $92.9 \mathrm{~b}$ \\
\hline H419-3-3-7-16-4-1 & $2.12 \mathrm{~b}$ & $56.73 \mathrm{c}$ & $56.6 \mathrm{c}$ & $92.9 \mathrm{~b}$ \\
\hline H419-10-6-2-5-1 & $2.07 \mathrm{c}$ & $54.63 \mathrm{c}$ & $57.6 \mathrm{c}$ & $90.4 \mathrm{~b}$ \\
\hline H419-10-6-2-10-1 & $2.01 \mathrm{c}$ & $56.09 \mathrm{c}$ & $57.9 \mathrm{c}$ & $94.8 \mathrm{~b}$ \\
\hline H419-10-6-2-12-1 & $2.03 \mathrm{c}$ & $55.37 \mathrm{c}$ & $56.3 \mathrm{c}$ & $93.4 \mathrm{~b}$ \\
\hline Catuaí 062 & $1.99 \mathrm{c}$ & $53.04 \mathrm{~d}$ & $55.8 \mathrm{c}$ & $99.8 \mathrm{a}$ \\
\hline
\end{tabular}

*Averages followed by same letter on the column belong to the same group by Scott-Knott test. 
TABLE 7 - Summary of analysis of variance with mean squares of area under the disease progress curve (AUDPC) for brown eye spot incidence (BEI), incidence of coffee leaf rust (LRI), brown eye spot severity (BES) and coffee leaf rust severity (LRS).

\begin{tabular}{cccccc}
\hline Source & DF & BEI & LRI & BES & LRS \\
\hline Genotype & 29 & $4247473 *$ & $944964 *$ & $10493 *$ & $7.8 *$ \\
Block & 3 & $3496037 *$ & 73137 & $8552 *$ & 0.87 \\
Error & 87 & 908544 & 135247 & 2436 & 1.08 \\
\hline
\end{tabular}

*Significant at 5\% probability at $\mathrm{F}$ test.

For the source of variation genotype, all response variables were significant. For coffee leaf rust, low severity values were observed, thus generating low AUDPC values. The susceptible Catuaí Amarelo IAC 62 cultivar showed the highest values of coffee leaf rust incidence and severity. Among the genotypes considered as tolerant or resistant, symptoms were observed, with spores, in Catucaí Amarelo 2SL, Catucaí Vermelho 785/15, Paraíso MG, IPR 59 and in the progenies H419-3-3-7-16-4-1, H419-10-6-2-5-1 and H419-10-6-2-10-1 (Table 8).

Higher values for coffee leaf rust incidence were observed from May to July, with highest disease occurrence in June.Susceptible cultivars behaved as classified, with a high incidence in Catuaí Amarelo IAC 62, with percentages higher than $41 \%$. For genotypes considered as tolerant or resistant, the incidence values were below $25 \%$. These genotypes with symptoms are derived from Icatu (Catucaí cultivars) and Timor Hybrid (Paraíso MG cultivar and progenies), both with C. canephora Pierre ex A. Froehner in their composition.

The resistance genes $\mathrm{SH} 1$ to $\mathrm{SH} 9$ interact with virulence genes v1 to $\mathrm{v} 9$ of the Hemileia vastatrix pathological agent. Genes SH1, 2, 4 and 5 have been identified in pure $C$. arabica from Ethiopia. The $\mathrm{SH} 3$ gene is cited as derived from C. liberica and the SH genes 6, 7, 8 and 9 from $C$. canephora. The SH gene series ensures complete resistance under homozygous conditions and when specific to the corresponding rust species/ gene. When the genes are broken, the plants show incomplete or partial resistance to the disease (SERA et al., 2010).

Carvalho (2011), in a study performed in producing regions of Minas Gerais, observed high susceptibility to coffee leaf rust for Oeiras derived from Timor Hybrid, showing values similar to controls. The Catiguá MG1, Catiguá MG3, Sacramento MG, Araponga MG, Paraíso
MG and Pau Brasil MG cultivars showed severity in intermediate indexes and Catiguá MG2 showed high resistance, with zero infection for all the evaluation sites. In the present study, among these cultivars mentioned above, sporulation symptoms were observed in Pau Brasil MG and also high resistance for Catiguá MG2.

In the Brazilian state of Paraná, Del Grossi (2011) identified cultivars derived from "Catucaí" germplasm as susceptible or with partial resistance levels. The author observed that in varieties from the Timor Hybrid such as Oeiras 6851, Acauã, Araponga MG, IPR 99, Obatã 1669-20, Tupi IAC 1669-33 and Sabiá 398, partial resistance were observed. The cultivars with complete resistance at the evaluated sites were Catiguá MG1 and MG2, IPR 59, 98 and 104, Palma II, Sacramento MG, Pau Brasil MG, and the progenies Paraíso H-41910-6-2-5-1, H-419-10-6-2-10-1 and H-419-10-62-12-1. When comparing with the present study, no symptoms were observed for the cultivars cited with partial resistance in the south of the country.

In the case of brown eye spot, a higher AUDPC was observed for incidence and severity in the Acauã cultivar, differing statistically from the other genotypes. It was followed by a group with IPR 98, IPR 99, IPR 59, Catucaí Vermelho 785/15, Catuaí Vermelho IAC 144, H419-3-3 -716-4-1, Sacramento MG 1, Topázio MG 1190, Catucaí Vermelho 20/15 cv 476, Paraíso MG 1 and Araponga MG. The IPR 103, Catiguá MG1 and MG3 cultivars showed the lowest absolute AUDPC values for disease incidence and severity (Table 8). Carvalho (2011) also found lower AUDPC values for Catiguá MG3 in some sites of Minas Gerais, Brazil. It should be noted that low disease incidence and severity, as in these Catiguá cultivars, with high resistance to coffee leaf rust and greater tolerance for the brown eyespot of coffee, do not imply in the higher yield found in the present study. 
TABLE 8 - Area under the disease progress curve (AUDPC) for brown eye spot incidence (BEI), coffee leaf rust incidence (LRI), brown eye spot severity (BES) and coffee leaf rust severity (LRS) for the 30 Coffea arabica genotypes in savanna conditions of central plateau.

\begin{tabular}{|c|c|c|c|c|c|}
\hline Treatment & Cultivar/Progeny & BEI & LRI & BES & LRS \\
\hline 1 & Catucaí Amarelo 2SL & $1866 \mathrm{a}$ & $436 \mathrm{a}$ & $146 \mathrm{a}$ & $5.1 \mathrm{~b}$ \\
\hline 2 & Catucaí Amarelo 24/137 & $2116 \mathrm{a}$ & $0 \mathrm{a}$ & $152 \mathrm{a}$ & $0 \mathrm{a}$ \\
\hline 3 & Catucaí Amarelo 20/15 cv 479 & $2147 \mathrm{a}$ & $0 \mathrm{a}$ & $175 \mathrm{a}$ & $0 \mathrm{a}$ \\
\hline 4 & Catucaí Vermelho 785/15 & $2866 \mathrm{~b}$ & $436 \mathrm{a}$ & $187 \mathrm{~b}$ & $4.4 \mathrm{~b}$ \\
\hline 5 & Catucaí Vermelho 20/15 cv 476 & $2522 b$ & $0 \mathrm{a}$ & $194 \mathrm{~b}$ & $0 \mathrm{a}$ \\
\hline 6 & Sabiá 398 & $1430 \mathrm{a}$ & $0 \mathrm{a}$ & $126 \mathrm{a}$ & $0 \mathrm{a}$ \\
\hline 7 & Palma II & $1648 \mathrm{a}$ & $0 \mathrm{a}$ & $107 \mathrm{a}$ & $0 \mathrm{a}$ \\
\hline 8 & Acauã & $6402 \mathrm{c}$ & $0 \mathrm{a}$ & $340 \mathrm{c}$ & $0 \mathrm{a}$ \\
\hline 9 & Oeiras MG 6851 & $1527 \mathrm{a}$ & $0 \mathrm{a}$ & $124 \mathrm{a}$ & $0 \mathrm{a}$ \\
\hline 10 & Catiguá MG 1 & $924 \mathrm{a}$ & $0 \mathrm{a}$ & $99 \mathrm{a}$ & $0 \mathrm{a}$ \\
\hline 11 & Sacramento MG 1 & $2831 \mathrm{~b}$ & $0 \mathrm{a}$ & $220 \mathrm{~b}$ & $0 \mathrm{a}$ \\
\hline 12 & Catiguá MG 2 & $1120 \mathrm{a}$ & $0 \mathrm{a}$ & $124 \mathrm{a}$ & $0 \mathrm{a}$ \\
\hline 13 & Araponga MG 1 & $2455 \mathrm{~b}$ & $0 \mathrm{a}$ & $194 \mathrm{~b}$ & $0 \mathrm{a}$ \\
\hline 14 & Paraíso MG 419-1 & $2490 \mathrm{~b}$ & $186 \mathrm{a}$ & $212 b$ & $2.5 \mathrm{~b}$ \\
\hline 15 & Pau Brasil MG 1 & $1804 \mathrm{a}$ & $0 \mathrm{a}$ & $156 \mathrm{a}$ & $0 \mathrm{a}$ \\
\hline 16 & Tupi IAC 1669-33 & $1854 \mathrm{a}$ & $0 \mathrm{a}$ & $152 \mathrm{a}$ & $0 \mathrm{a}$ \\
\hline 17 & Obatã Vermelho IAC 1669-20 & $1836 \mathrm{a}$ & $0 \mathrm{a}$ & $149 \mathrm{a}$ & $0 \mathrm{a}$ \\
\hline 18 & IPR 59 & $3084 \mathrm{~b}$ & $31 \mathrm{a}$ & $226 \mathrm{~b}$ & $0.33 \mathrm{a}$ \\
\hline 19 & IPR 98 & $3430 \mathrm{~b}$ & $0 \mathrm{a}$ & $209 \mathrm{~b}$ & $0 \mathrm{a}$ \\
\hline 20 & IPR 99 & $3360 \mathrm{~b}$ & $0 \mathrm{a}$ & $230 \mathrm{~b}$ & $0 \mathrm{a}$ \\
\hline 21 & IPR 103 & $1010 \mathrm{a}$ & $0 \mathrm{a}$ & $93 \mathrm{a}$ & $0 \mathrm{a}$ \\
\hline 22 & IPR 104 & $2151 \mathrm{a}$ & $0 \mathrm{a}$ & $166 \mathrm{a}$ & $0 \mathrm{a}$ \\
\hline 23 & Catiguá MG 3 & $1027 \mathrm{a}$ & $0 \mathrm{a}$ & $100 \mathrm{a}$ & $0 \mathrm{a}$ \\
\hline 24 & Topázio MG 1190 & $2553 \mathrm{~b}$ & $125 \mathrm{a}$ & $193 \mathrm{a}$ & $2.4 \mathrm{~b}$ \\
\hline 25 & Catuaí Vermelho IAC 144 & $2860 \mathrm{~b}$ & $746 \mathrm{a}$ & $217 \mathrm{~b}$ & $9.4 \mathrm{~b}$ \\
\hline 26 & H419-3-3-7-16-4-1 & $2836 \mathrm{~b}$ & $375 a$ & $214 b$ & $5.6 \mathrm{~b}$ \\
\hline 27 & H419-10-6-2-5-1 & $2151 \mathrm{a}$ & $63 \mathrm{a}$ & $175 \mathrm{a}$ & $1.3 b$ \\
\hline 28 & H419-10-6-2-10-1 & $1806 \mathrm{a}$ & $374 \mathrm{a}$ & $145 \mathrm{a}$ & $5.0 \mathrm{~b}$ \\
\hline 29 & H419-10-6-2-12-1 & 1929 a & $0 \mathrm{a}$ & $170 \mathrm{a}$ & $0 \mathrm{a}$ \\
\hline 30 & Catuaí Amarelo IAC 62 & $1900 \mathrm{a}$ & $2555 \mathrm{~b}$ & $152 \mathrm{a}$ & $56.3 \mathrm{c}$ \\
\hline
\end{tabular}

*Averages followed by same letter on the column belong to the same group by Scott-Knott test.

Considering the brown eye spot of coffee, two peaks occurred in February and another in July, coinciding with the period of granulation and pre-harvest of coffee fruits, demonstrating the relationship with the crop load. These two disease peaks were also found by Custódio et al. (2014), in the months of March and June of 2005 and 2006, in Lavras-MG county. The disease occurrence in the periods near the harvest can be related to the plant's nutritional imbalance to the detriment of the end of the bean filling, leaving the plant more susceptible to the pathogen attack (CARVALHO, 2011; CUSTÓDIO et al., 2014). 
According to the results, cultivars with considerable yield and susceptible to pathogens in the assessed environment could be recommended by using fungicide control, together with the adequate use of mineral nutrition, possibly providing better yields than obtained in the present research. However, in order to reduce production costs and risks to rural workers and to the environment, and still possibly increasing the income, there are options of cultivars with high yield, good vegetative growth and high resistance to diseases, mainly coffee leaf rust for the edaphoclimatic conditions of the central savanna region.

\section{CONCLUSIONS}

The Catucaí 2SL, Sacramento MG and Araponga MG cultivars stood out in vegetative growth in the savanna conditions of central plateau. Cultivars with the highest average yield, above 60 bg.ha- ${ }^{1}$, IPR 103, Obatã Vermelho 166920, Palma II, Sabiá 398 and Acauã showed greater adaptability to the environmental conditions. Among all these cultivars is observed high resistance to rust leaf and greater susceptibility to brown eye spot in the cultivar Acauã, for the place and period of evaluation

\section{REFERENCES}

ANGELICO, C. L. et al. Diferentes estádios de maturação e tempo de ensacamento sobre a qualidade do café. Coffee Science, Lavras, v. 6, n. 1, p. 8-19, jan./ abr. 2011.

ANTHONY, F. et al. Genetic diversity of wild coffee (Coffea Arabica L.) using molecular markers. Euphytica,Wageningen, v. 118, p. 53-65, 2001.

CARVALHO, A. M. Desempenho agronômico de cultivares de cafeeiro resistentes à ferrugem. 2011. 89 p. Tese (Doutorado em Fitotecnia)-Universidade Federal de Lavras, Lavras, 2011.

CARVALHO, A. M. et al. Desempenho agronômico de cultivares de café resistentes à ferrugem no Estado de Minas Gerais. Bragantia, Campinas, v. 71, n. 4, p. 481487, 2012.

COMPANHIA NACIONAL DE ABASTECIMENTO. Acompanhamento da safra brasileira: café, v. 2, safra 2016, n. 1, primeiro levantamento. Brasília, DF, 2016.68 p.

CUSTODIO, A. A. de P. et al. Effect of center-pivot irrigation in the rust and brown eye spot of coffee. Plant Disease, Saint Paul, v. 98, p. 943-947, 2014.
DEL GROSSI, L. Resistencia à ferrugem de cultivares de café arábica no Norte do Paraná. 2011. 59 p. Dissertação (Mestrado em Agronomia)-Universidade Estadual de Londrina, Londrina, 2011.

FERNANDES, A. L. T. et al. A moderna cafeicultura dos cerrados brasileiros. Pesquisa Agropecuária Tropical, Goiânia, v. 42, n. 2, p. 231-240, abr.jun. 2012.

FERREIRA, A. et al. Seleção simultânea de Coffea canefora por meio da combinação de análise de fatores e índices de seleção. Pesquisa Agropecuária Brasileira, Brasília, DF, v. 40, p. 1189-1195, 2005.

FERREIRA, D. F. Sisvar: a computer statistical analysis system. Ciência e Agrotecnologia, Lavras, v. 35, n. 6, p. 1039-1042, nov./dez. 2011.

FREITAS, Z. M. T. S. et al. Avaliação de caracteres quantitativos relacionados com o crescimento vegetativo entre cultivares de café arábica de porte baixo. Bragantia, Campinas, v. 66, p. 267-275, 2007.

GARÇON, C. L. P. et al. Controle da ferrugem do cafeeiro com base no valor de severidade. Fitopatologia Brasileira, Brasília, DF, v. 29, p. 486-491, 2004.

GUERRA, A. F.; ROCHA, O. C.; RODRIGUES, G. C. Manejo do cafeeiro irrigado no Cerrado com estresse hídrico controlado. ITEM, Irrigação e Tecnologia Moderna, Brasília, DF, n. 65/66, p. 42-45, 2005.

MARIOTTI, J. A. et al. Analisis de estabilidad y adaptabilidad de genotipos de canã de azucar: I., interaciones dentro de una localidad experimental. Revista Agronomica del Noroeste Argentino, Tuculman, v. 13, n. 1/4, p. 105-127, 1976.

MARTINS, S. J. et al. Contribution of host and environmental factors to the hyperparasitism of coffee rust under field conditions. Australasian Plant Pathology, Clayton, v. 44, p. 605-610, 2015.

PAIVA, B. R. T. L. et al. Progresso da ferrugem do cafeeiro irrigado em diferentes densidades de plantio pós-poda. Ciência e Agrotecnologia, Lavras, v. 35, n. 1, p. 137-143, jan./fev. 2011.

SERA, G. H. et al. Resistance to leaf rust in coffee cultivars. Coffee Science, Lavras, v. 5, n. 1, p. 59-66, jan./abr. 2010. 
SOUZA, A. G. C.; MAFFIA, L. A.; MIZUBUTI, E. S. G. Cultural and Aggressiveness variability of Cercospora coffeicola. Journal of Phytopathology, West Sussex, v. 160, p. 540-546, 2012.
TEIXEIRA, A. L. et al. Performance of arábica coffee cultivars under high temperature conditions. African Journal of Agricultural Research, Nairobi, v. 8, n. 33, p. 4402-4407, 2013. 